\title{
TINGKAT PENERAPAN TEKNOLOGI PENGELOLAAN TANAMAN TERPADU (PTT) PADA USAHATANI PADI SAWAH (ORYZA SATIVA L.) (Suatu Kasus Di Desa Rejasari Kecamatan Langensari Kota Banjar)
}

\author{
Oleh: \\ Teti Tresnaningsih ${ }^{1}$, Dedi Herdiansah $\mathbf{S}^{2}$, Tito Hardiyanto ${ }^{3}$ \\ ${ }^{1,2,3}$ Fakultas Pertanian Universitas Galuh
}

\begin{abstract}
ABSTRAK
Tujuan penelitian penulis adalah untuk melihat tingkat keberhasilan tingkat penerapan teknologi model PTT, dan kendala yang dihadapi petani dalam hal penerapan teknologi PTT. Penentuan daerah penelitian dilakukan secara purposive sampling, yaitu dengan sengaja di desa Rejasari Kecamatan Langensari Kota Banjar yang didasarkan bahwa desa Rejasari merupakan desa yang terbanyak kelompoktani yang menerapkan teknologi model PTT tersebut, untuk responden diambil petani sebanyak 34 orang, sedangkan untuk melihat tingkat keberhasilan penerapan teknologi model PTT menggunakan scoring. Hasil penelitian tingkat penerapan teknologi PTT adalah:

1) Dalam tingkat penerapan komponen teknologi dasar termasuk dalam kategori sedang, sedangkan dalam tingkat penerapan komponen teknologi pilihan termasuk dalam kategori tinggi.

2) Masih ada beberapa kendala yang dihada pi petani diantaranya: (a) Penerapan teknik sistem tanam jajar legowo dengan jajar legowo 2:1 dan jajar legowo 4:1 belum bisa dilaksanakan oleh sebagian besar petani. (b) Penanaman bibit 1 sampai 3 per rumpun belum bisa dilaksanakan secara maksimal, karena masih ditemukannya serangan hama keong mas.
\end{abstract}

\section{Kata Kunci: Tingkat Penerapan teknologi, Komponen PTT}

\section{PENDAHULUAN}

\section{Latar Belakang}

Pengembangan sektor tanaman pangan merupakan salah satu strategi kunci dalam memacu pertumbuhan ekonomi pada masa yang akan datang. Selain berperan sebagai sumber penghasil devisa yang besar, juga merupakan sumber kehidupan bagi sebagian besar penduduk Indonesia (Kementerian Pertanian Republik Indonesia, 2013).

Lebih lanjut Kementerian Pertanian Republik Indonesia (2013) menyatakan bahwa salah satu strategi yang dilakukan dalam upaya memacu peningkatan produksi dan produktivitas usahatani padi dan jagung adalah dengan mengintegrasikan antar sektor dan antar wilayah dalam pengembangan usaha pertanian di Indonesia.

Komoditi tanaman pangan memiliki peranan pokok sebagai pemenuh kebutuhan pangan, pakan dan industri dalam negeri yang setiap tahunnya cenderung meningkat seiring dengan pertambahan jumlah penduduk dan berkembangnya industri pangan dan pakan sehingga kebutuhan akan pangan bagi mahluk hidup dari sisi Ketahanan Pangan Nasional fungsinya menjadi amat penting dan strategis (Kementerian Pertanian Republik Indonesia, 2013).
Usahatani sangat dipengaruhi keadaan iklim, curah hujan, ketersediaan air irigasi, oleh karena itu teknologi usahatani yang sesuai untuk suatu lokasi belum tentu sesuai untuk lokasi lainnya. Dalam kaitan itu harus didasarkan oleh hasil penelitian di lokasi yang bersangkutan. Untuk itu pula dilakukan percobaan kesesuain varietas, bercocok tanam, pemupukan, pemberantasan hama dan lainnya dilahan petani. Partisipasi petani dimulai dengan penggunaan lahannya untuk percobaan teknologi baru dan sekaligus sebagai etalase bagi teknologi baru untuk meyakinkan petani lain tentang keberhasilan teknologi baru yang dicoba (Slamet, 2003).

Menurut Kementerian Pertanian Republik Indonesia (2013) Salah satu strategi yang dilakukan dalam upaya memacu peningkatan produksi dan produktivitas usahatani padi, jagung dan kedele adalah dengan mengintegrasikan antar sektor dan antar wilayah dalam pengembangan usaha pertanian dalam rangka mensukseskan ketahanan pangan melalui program teknologi pengelolaan tanaman terpadu.

Peningkatan Produktivitas usaha tanaman padi sangat dibutuhkan dalam rangka pemenuhan kebutuhan pangan rakyat Indonesia. Dimana padi merupakan bahan makanaan pokok masyarakat Indonesia. Untuk itu Balai pengkajian Teknologi Pertanian menciptakan komponen teknologi PTT 
yaitu Pengelolaan tanaman terpadu yang terdiri dari 12 komponen teknologi (Balai Pengkajian Teknologi Pertanian 2011). Peningkatan produksi beras nasional sekitar 2 juta ton dapat dicapai melalui peningkatan luas panen sekitar $0-1 \%$; peningkatan produktivitas sekitar $6 \%$ dan peningkatan produksi sekitar 5-7\%. Upaya peningkatan luas panen, produktivitas dan produksi salah satunya dilakukan melalui penerapan teknologi dengan pendekatan Pengelolaan Tanaman dan Sumberdaya Terpadu (PTT) dengan metode Sekolah Lapangan (SL).

Untuk Meningkatkan produksi di Kota banjar telah dilaksanakan program penerapan PTT melalui kegiatan SL-PTT, menurut Balai penyuluhan pertanian Kecamatan Langensari (2014) bahwa penyebar luasan teknologi PTT di Kecamatan Langensari telah dilaksanakan melalui pelaksanaan SL-PTT pada kelompok tani yang tersebar di seluruh desa yang ada di wilayah Kecamatan Langensari, namun pada kenyataannya teknologi PTT tersebut belum sepenuhnya diadopsi oleh para petani, bahkan dalam penggunaan benih unggul dan pemberian pupuk organik dan teknik tanam jajar legowo masih belum diterapkan dalam proses usahatani padi sawah.

\section{Tujuan Penelitian}

Penelitian ini bertujuan untuk mengetahui:

1. Tingkat penerapan teknologi PTT pada usahatani padi sawah di Desa Rejasari Kecamatan Langensari Kota Banjar.

2. Kendala yang dihadapi petani dalam pelaksanaan sistem pengelolaan tanaman terpadu di Desa Rejasari Kecamatan Langensari Kota Banjar.

\section{TINJAUAN PUSTAKA}

\section{Budidaya Padi Sistem PTT (Pengelolaan Tanaman Terpadu)}

Padi merupakan bahan makanan yang menghasilkan beras. Bahan mskanan ini merupakan makanan pokok sebagian besar penduduk Indonesia. Walaupun padi dapat digantikan oleh makanan lainnya, namun padi mempunyai nilai tersendiri bagi orang yang biasa makan nasi dan tidak mudah digantikan oleh bahan makanan lainnya. Padi dibudidayakan dengan tujuan mendapatkan hasil yang setinggitingginya dengan kualitas sebaik mungkin, untuk mendapatkan hasil yang baik maka tanaman yang akan ditanam harus sehat dalam artian bebas dari hama dan penyakit (Dinas Pertanian Tanaman Pangan, 2013).

Selanjutnya Dinas Pertanian Tanaman Pangan, 2013 menyatakan bahwa untuk meningkatkan produksi beras dalam rangka pencapaian swasembada pangan, diperlukan upaya terobosan rekayasa teknologi, sosial, ekonomi dan kelembagaan yang dapat diterapkan dalam waktu segera. Salah satunya adalah peningkatan produktivitas melalui pendekatan Pengelolaan Tanaman Terpadu (PTT).

Pengelolaan Tanaman Terpadu (Integrated Crop Management) atau lebih dikenal dengan PTT padi sawah, merupakan salah satu model atau pendekatan pengelolaan usahatani padi, dengan mengimplementasikan berbagai komponen teknologi budidaya yang memberikan efek sinergis. PTT menggabungkan semua komponen usahatani terpilih yang serasi dan saling berhubungan, untuk mendapatkan hasil panen yang optimal dan menjaga kelestarian lingkungan (Sumarno, 2000).

Selanjutnya Balai Pengkajian Teknologi Pertanian (2011) menyatakan bahwa Pengelolaan Tanaman dan Sumberdaya Terpadu atau disingkat PTT adalah pendekatan dalam upaya mengelola lahan, air, tanaman, OPT dan iklim secara terpadu/menyeluruh/holistic dan dapat diterapkan secara lumintu (berkelanjutan). PTT dapat diilustrasikan sebagai sistem pengelolaan yang menggabungkan berbagai sub sistem pengelolaan, seperti sub sistem pengelolaan hara tanaman, Konservasi tanah dan air, Bahan organik dan organisme tanah, Tanaman (benih, varietas, bibit, populasi tanaman dan jarak tanam), Pengendalian hama dan penyakit/ organisme pengganggu tanaman, dan Sumberdaya manusia.

\section{METODE PENELITIAN Jenis Penelitian}

Metode penelitian yang digunakan dalam penelitian ini adalah metode survei yang dilakukan di Desa Rejasari Kecamatan Langensari Kota Banjar, dengan mengambil kasus petani padi sawah yang menerapkan teknologi pengelolaan tanaman terpadu. Menurut Daniel (2002) metode survei adalah pengamatan atau penyelidikan yang kritis untuk mendapatkan keterangan yang baik terhadap suatu proses persoalan tertentu di dalam daerah atau lokasi tertentu, atau studi ekstensif yang dipolakan untuk memperoleh informasi-informasi yang dibutuhkan. 


\section{Operasionalisasi Variabel}

Untuk memperjelas dan mempermudah penafsiran dalam penelitian ini, maka variabelvariabel yang diteliti didefinisikan sebagai berikut:

1. Pengelolaan Tanaman Terpadu atau PTT adalah pendekatan dalam upaya mengelola lahan, tanaman, air, Organisme Pengganggu Tanaman (OPT) dan iklim secara terpadu dan menyeluruh yang diterapkan secara berkelanjutan.

2. Komponen Teknologi Dasar atau komponen teknologi utama adalah teknologi di dalam PTT yang memiliki pengaruh yang besar atau berkontribusi tinggi terhadap peningkatan produktivitas atau hasil panen. Agar peningkatan produktivitas terjadi secara nyata (signifikan), maka komponen teknologi yang tergolong ke dalam teknologi dasar harus diterapkan secara dengan baik dan benar. Penilaian dilakukan dengan sisitem skoring.

3. Benih Bermutu atau Benih Berkualitas atau Benih Bersertifikat adalah benih yang murni secara genetik sebagai pembawa potensi genetik suatu varietas, matang secara fisiologis dan memenuhi persyaratan mutu fisik berdasarkan prosedur pengujian untuk mendapatkan sertifikat (sertifikasi). Dalam sertifikasi benih, maka prosedur yang harus dilalui diantaranya pemeriksaan lapangan, pemeriksaan gudang dan peralatan, pengawasan terhadap benih yang sedang diolah serta pemeriksaan laboratorium. Karakteristik yang mencerminkan mutu benih antara lain asli (genuine, authentic), mencerminkan karakteristik varietas yang diwakilinya, murni (tidak tercampur offtypes), bersih dari kotoran (biji, gulma, tanaman lain, inert matter, immature seed), bernas, hidup (viable, tumbuh bila ditanam) dan sehat (tidak mengandung penyakit) dengan ketentuan persyaratan masing-masing berbeda sesuai dengan kelas benihnya.

4. Varietas adalah sekelompok tanaman dari suatu jenis atau spesies yang ditandai oleh bentuk tanaman, pertumbuhan tanaman, daun, bunga, buah, biji dan ekspresi karakteristik genotipe atau kombinasi genotipe yang dapat membedakan dari jenis atau spesies yang sama oleh sekurang-kurangnya satu sifat yang menentukan dan apabila diperbanyak tidak mengalami perubahan.
5. Varietas Unggul adalah varietas yang telah dilepas oleh pemerintah yang mempunyai kelebihan dalam potensi hasil dan/atau sifatsifat lainnya. Varietas unggul dapat berupa hasil pemuliaan, baik melalui cara konvensional biasanya disebut sebagai Varietas Unggul Inbrida, melalui cara inkonvensional/ non-konvensional biasanya disebut sebagai Varietas Unggul Hibrida maupun introduksi atau dapat pula berupa varietas lokal disebut sebagai Varietas Unggul Lokal.

6. Pengendalian OPT adalah Perlindungan tanaman dilaksanakan untuk mangantisipasi dan mengendalikan serangan OPT tanaman, dengan meminimalkan kerusakan atau penurunan yang dilakukan berdasarkan pengendalian hama terpadu (PHT). Khusunya pengendalian dengan pestisida merupakan pilihan terakhir bila serangan OPT berada di atas ambang ekonomi. Penggunaan pestisida harus memperhatikan jenis, jumlah dan cara penggunaannya, sesuai dengan ketentuan dan peraturanyang berlaku sehingga tidak menimbulkan resurjensi atau resistensi OPT atau dampak lain yang merugikan lingkungan.

7. Komponen Teknologi Pilihan atau komponen teknologi alternatif adalah teknologi di dalam PTT yang memiliki pengaruh atau kontribusi terhadap peningkatan produktivitas/hasil panen, walaupun pengaruhnya tidak sebesar pengaruh akibat penerapan teknologi dasar atau utama. Penilaian dilakukan dengan sisitem skoring.

\section{Teknik Pengumpulan Data}

Data yang akan dikumpulkan dalam penelitian ini meliputi data primer dan data sekunder Data primer diperoleh dari petani responden melalui wawancara sedangkan data sekunder diperoleh melalui data dan informasi dari intansi Dinas Pertanian dan Ketahanan Pangan Kota Banjar, Kantor Balai Penyuluhan Pertanian (BPP) kecamatan Langensari, Kantor Kecamatan Langensari, Kantor Desa Rejasari maupun melalui penelusuran literatur.

\section{Teknik Penarikan Sampel}

Teknik penarikan sampel yang digunakan dalam penelitian ini adalah teknik penarikan sampel secara sengaja (purposive sampling) dimana Desa Rejasari dipilih atas dasar 
pertimbangan mempunyai kelompoktani terbanyak. Untuk menentukan jumlah sampel responden dengan menggunakan metode Proportional random sampling. Berdasarkan pendapat Arikunto (2002), bila jumlah populasi kurang dari 100 dapat diambil seluruhnya, tetapi bila lebih dari 100 dapat diambil sebesar 10, 15, 25 persen dari populasi. Jumlah sampel dalam penelitian ini ditentukan sebanyak 10 persen dari jumlah anggota populasi sebanyak 338 orang, jadi yang terpilih sebagai sampel dan dijadikan responden sebanyak 34 orang.

\section{Rancangan Analisis Data}

Dalam penerapan tingkat PTT pada usahatani padi sawah di Desa Rejasari dibagi ke dalam tiga kategori. Untuk menentukan panjang kelas masing-masing kategori menurut
(Sudjana,2000) dilakukan perhitungan sebagai berikut:

$$
\begin{aligned}
\text { Panjang Kelas Interval } & =\frac{\text { rentang }}{\text { Jumlah Kelas }} \\
& =\frac{\text { Nilai Maksimal }- \text { Nilai Minimal }}{\text { Jumlah Kategori }}
\end{aligned}
$$

Keterangan:

Nilai Maksimal: Nilai tertinggi dari masingmasing variable dan indikatornya

Nilai Minimal: Nilai terendah dari masingmasing variable dan indikatornya

Penentuan skor untuk mengukur tingkat penerapan teknologi PTT dilakukan dengan penilaian sebagaimana dapat dilihat pada tabel 1, sedangkan untuk mengetahui kendala-kendala yang dihadapi petani dalam penerapan PTT pada usahatani padi sawah dianalisis sacara deskriptif.

Tabel 1. Kategori Penerapan Teknologi PTT

\begin{tabular}{|c|l|c|c|}
\hline No & \multicolumn{1}{|c|}{ Variabel Indikator } & Nilai Minimum & Nilai Maximum \\
\hline $\mathbf{1}$ & Teknologi Dasar PTT: & 2,000 & \\
& - Varietas Unggul & 2,000 & 6,000 \\
& - Benih Bermutu & 2,000 & 6,000 \\
& - Populasi Tanaman & 3,000 & 6,000 \\
& - Pupuk Anorganik & 3,000 & 9,000 \\
& - Pupuk Organik & 3,000 & 9,000 \\
& - Pengendalian OPT & 15,000 & 9,000 \\
\hline \multicolumn{2}{|c|}{ Jumlah } & & 45,000 \\
\hline $\mathbf{2}$ & Teknologi Pilihan PTT: & 2,000 & 6,000 \\
& - Pengolahan tanah & 2,000 & 6,000 \\
& - Bibit muda & 2,000 & 6,000 \\
& - Tanam per rumpun & 2,000 & 6,000 \\
& - Pengairan efektif & 2,000 & 6,000 \\
& - Pemakaian gasrok & 3,000 & 9,000 \\
\hline \multicolumn{2}{|c|}{ - Panen dan pasca panen } & 13,000 & 39,000 \\
\hline \multicolumn{2}{|c|}{ Total } & 28,000 & 84,000 \\
\hline
\end{tabular}

Interval masing-masing kategori sebagai berikut:

1) Tingkat penerapan teknologi PTT
a. Rendah : 46,66>Q $\geq 28,00$
b. Sedang $\quad: 65,33>Q \geq 46,67$
c. Tinggi
$: 84,00 \geq \mathrm{Q} \geq 65,33$

2) Tingkat penerapan teknologi dasar PTT
a. Rendah : 25,00>Q $\geq 15,00$
b. Sedang $\quad: 35,00>Q \geq 25,00$
c. Tinggi $\quad: 45,00 \geq Q \geq 35,00$

3) Tingkat penerapan teknologi pilihan PTT

a. Rendah : 21,67>Q $\geq 13,00$

b. Sedang $: 30,34>Q \geq 21,67$

c. Tinggi : $39,00 \geq Q \geq 30,34$

Keterangan: $\mathrm{Q}$ adalah nilai yang dicapai

\section{Tempat dan Waktu Penelitian}

Penelitian ini dilaksanakan di Desa Rejasari Kecamatan Langensari Kota Banjar dengan pertimbangan bahwa daerah tersebut merupakan salah satu sentra produksi padi sawah dan mempunyai produktivitas tinggi dan mempunyai Kelompoktani terbanyak dalam kegiatan SL-PTT dari Desa yang lainnya khususnya di Kecamatan Langensari Kota Banjar.

Adapun waktu penelitian dimulai dari tahap persiapan bulan maret, tahap pengumpulan data bulan april dan pengolahan data sampai penulisan dimulai bulan mei sampai selesai. 


\section{HASIL DAN PEMBAHASAN}

Lahan di Desa Rejasari secara keseluruhan mencapai luas 589,63 hektar. Dengan jumlah penduduk sebanyak 10.139 orang. Dengan lahan sawah seluas 328,22 hektar atau 55,66 persen dari luas keseluruhan wilayah, yang terdiri dari sawah berpengairan irigasi teknis seluas 227 hektar atau 38,49 persen dan sawah tadah hujan dengan luas 101,22 hektar atau 17,17 persen dari luas keseluruhan wilayah.

\section{Kajian Penerapan Teknologi PTT}

Tingkat penerapan teknologi PTT pada usahatani padi sawah dinyatakan berdasarkan nilai skor. Kriteria yang digunakan untuk memenuhi tingkat penerapan teknologi PTT pada usahatani padi sawah oleh para anggota kelompoktani, dibagi dalam tiga katogeri sebagaimana diuraikan pada metode penelitian. Berdasarkan hasil perhitungan diketahui, bahwa tingkat penerapan teknologi PTT yang dicapai oleh para petani responden yang tergabung dalam kelompoktani dapat dilihat pada tabel 2 .

Tabel 2. Tingkat Penerapan Teknologi PTT

\begin{tabular}{|l|l|c|c|c|}
\hline No. & $\begin{array}{c}\text { Kategori Tingkat } \\
\text { Penerapan }\end{array}$ & $\begin{array}{c}\text { Nilai } \\
\text { (Kisaran Skor) }\end{array}$ & $\begin{array}{c}\text { Jumlah Petani } \\
\text { (Orang) }\end{array}$ & $\begin{array}{c}\text { Persentase } \\
(\boldsymbol{\%})\end{array}$ \\
\hline 1. & Rendah & $46,66>\mathrm{Q} \geq 28,00$ & 0 & 0,00 \\
\hline 2. & Sedang & $65,33>\mathrm{Q} \geq 46,67$ & 12 & 35,29 \\
\hline 3. & Tinggi & $84,00 \geq \mathrm{Q} \geq 65,33$ & 22 & 64,71 \\
\hline & Jumlah & & $\mathbf{3 4}$ & $\mathbf{1 0 0 , 0 0}$ \\
\hline
\end{tabular}

Berdasarkan tabel 4 diketahui bahwa sebagian besar petani responden yaitu sebanyak 22 orang tingkat penerapan teknologi PTT pada usahatani padi sawahnya termasuk ke kategori tinggi. Hal tersebut menunjukan, bahwa para petani padi sawah di Desa Rejasari secara umum telah memahami pentingnya penerapan teknologi PTT pada usahatani padi sawahnya, dalam rangka meningkatkan hasil usahataninya, meskipun teknologi PTT tersebut belum sepenuhnya dapat diterapkan oleh petani, terutama untuk komponen teknologi dasar yang sebagian besar baru mencapai kategori sedang. Teknologi PTT belum sepenuhnya dapat diadopsi oleh para petani, terutama dalam penerapan teknologi dasar, tetapi secara umum tinginya tingkat penerapan PTT pada usahatani padi sawah di Desa Rejasari tidak lepas dari adanya bantuan kegiatan SL-PTT dari pihak pemerintah, yang sampai saat ini masih dipandang sebagai metode yang cukup efektif dan efisien, terutama dalam proses penyebarluasan inovasi teknologi di bidang pertanian.

\section{Tingkat Penerapan Komponen Teknologi Dasar PTT}

Berdasarkan hasil penelitian diketahui, bahwa untuk komponen teknologi dasar PTT, dalam tingkat penerapannya oleh petani responden, sebagian besar termasuk dalam kategori sedang, sebagaimana dapat dilihat pada tabel 3 .

Tabel 3. Tingkat Penerapan Teknologi Dasar PTT

\begin{tabular}{|l|l|c|c|c|}
\hline No. & $\begin{array}{c}\text { Kategori Tingkat } \\
\text { Penerapan }\end{array}$ & $\begin{array}{c}\text { Nilai } \\
\text { (Kisaran Skor) }\end{array}$ & $\begin{array}{c}\text { Jumlah Petani } \\
\text { (Orang) }\end{array}$ & $\begin{array}{c}\text { Persentase } \\
\text { (\%) }\end{array}$ \\
\hline 1. & Rendah & $25,00>\mathrm{Q} \geq 15,00$ & 0 & 0,00 \\
\hline 2. & Sedang & $35,00>\mathrm{Q} \geq 25,00$ & 18 & 52,94 \\
\hline 3. & Tinggi & $45,00 \geq \mathrm{Q} \geq 35,00$ & 16 & 47,06 \\
\hline & Jumlah & & $\mathbf{3 4}$ & $\mathbf{1 0 0 , 0 0}$ \\
\hline
\end{tabular}

Tabel 3 Menunjukan bahwa sebagian besar petani responden yaitu sebanyak 18 orang atau 52,94 persen, tingkat penerapan teknologi dasar PTT pada usahatani padi sawahnya mencapai katgori sedang. Hal tersebut disebabkan adanya beberapa factor yang menghambat dalam proses penerapannya, terutama dalam penanaman sitem jajar legowo $2: 1$, pupuk dan pengendalian OPT dalam hal ini akibat dari penanaman 1-3 rumpun per lubang. 


\section{Tingkat Penerapan Teknologi Pilihan PTT}

Hasil dari penelitian yang dilakukan pada petani responden dalam hal penerapan teknologi pilihan PTT pada usahatani padi sawah relatif cukcup berhasil, dikarenakan sebagian besar petani responden tingkat penerapannya mencapai kategori tinggi. Untuk lebih jelasnya tingkat penerapan teknologi pilihan dapat dilihat pada tabel 4 .

Tabel 4. Tingkat Penerapan Teknologi Pilihan PTT

\begin{tabular}{|l|l|c|c|c|}
\hline No. & $\begin{array}{c}\text { Kategori Tingkat } \\
\text { Penerapan }\end{array}$ & $\begin{array}{c}\text { Nilai } \\
\text { (Kisaran Skor) }\end{array}$ & $\begin{array}{c}\text { Jumlah Petani } \\
\text { (Orang) }\end{array}$ & $\begin{array}{c}\text { Persentase } \\
(\mathbf{\%})\end{array}$ \\
\hline 1. & Rendah & $21,67>\mathrm{Q} \geq 13,00$ & 0 & 0,00 \\
\hline 2. & Sedang & $30,34>\mathrm{Q} \geq 21,67$ & 6 & 17,65 \\
\hline 3. & Tinggi & $39,00 \geq \mathrm{Q} \geq 30,34$ & 28 & 82,35 \\
\hline & Jumlah & & $\mathbf{3 4}$ & $\mathbf{1 0 0 , 0 0}$ \\
\hline
\end{tabular}

Berdasarkan tabel 4 diketahui bahwa sebagian besar petani responden yaitu sebanyak 28 orang atau 82,35 persen, tingkat penerapan teknologi pilihan PTT pada usahatani padi sawahnya termasuk kategori tinggi. Hal tersebut menunjukan bahwa para petani telah menyadari pentingnya penerapan teknologi pilihan PTT dalam upaya meningkatkan hasil usahatani padi sawah yang di usahakannya.

Komponen Teknologi Pilihan atau komponen teknologi alternatif adalah teknologi di dalam PTT yang memiliki pengaruh atau kontribusi terhadap peningkatan produktivitas/hasil panen, walaupun pengaruhnya tidak sebesar pengaruh akibat penerapan teknologi dasar atau utama.

Berbeda dengan komponen teknologi dasar yang sangat dipengaruhi oleh factor luar dalam hal ini ketersediaan sarana produksi, untuk komponen teknologi pilihan lebih dominan factor individu, sehingga setelah para petani mengikuti kegiatan SL-PTT dan menyadari pentingnya teknologi tersebut untuk diterapkan pada usahataninya, maka muncul dorongan yang kuat untuk menerapkan teknologi pilihan tanpa banyak hambatan, meskipun tidak semua petani menerapkan sepenuhnya teknologi yang direkomendasikan.

\section{Kendala yang Dihadapi Petani dalam Penerapan Teknologi PTT}

Secara umum penerapan teknologi PTT di Desa Rejasari Kecamatan Langensari Kota Banjar sudah cukup baik, karena sebagai besar penerapannya telah mencapai kategori tinggi, namun demikiaan masih ada beberapa kendala yang dihadapi antara lain :

1) Penerapan teknik sistem tanam jajar legowo dengan teknik jajar legowo 2:1 dan 4;1 belum bisa dilaksanakan oleh sebagian besar petani, dikarenakan petani belum terbiasa untuk melakukan teknik sistem jajar legowo 2:1 dan $4: 1$, serta beranggapan bila melakukan teknik tersebut adanya pemborosan lahan yang mengakibatkan populasi berkurang, sehingga akan berpengaruh tehadap produksi.

2) Penanaman bibit 1 sampai 3 per rumpun belum bisa dilaksanakan secara maksimal, karena masih ditemukannya serangan hama keong mas, sehingga petani masih melakukan cara tanam dengan cara ombol (banyak).

\section{KESIMPULAN DAN SARAN \\ Kesimpulan}

Berdasarkan hasil penelitian dan pembahasan, maka dapat diambil kesimpulan sebagai berikut:

1. Sebagian besar petani responden yaitu sebanyak 22 orang atau 64,71 persen tingkat penerapan teknologi PTT pada usahatani padi sawah termasuk dalam kategori tinggi dan pada komponen teknologi dasar PTT tingkat penerapan yang dicapai oleh petani responden sebagian besar masuk pada kategori sedang, yaitu sebanyak 18 orang atau 52,94 persen, sedangkan pada komponen teknologi pilihan PTT tingkat penerapan teknologi yang dicapai oleh petani responden termasuk dalam kategori tinggi yaitu sebanyak 28 orang atau 82,35 persen.

2. Secara umum penerapan teknologi PTT di Desa Rejasari kecamatan Langensari Kota Banjar sudah mendekati optimal dalam tingkat penerapan teknologinya, namun masih ada beberapa kendala yang dihadapi diantaranya:

a. Penerapan teknik sistem tanam jajar legowo dengan teknik jajar legowo 2:1 dan jajar legowo 4:1 belum bisa dilaksanakan oleh sebagian besar petani. Petani masih 


\section{Tingkat Penerapan Teknologi Pengelolaan Tanaman Terpadu (PTT) \\ Pada Usahatani Padi Sawah (Oryza Sativa L.) \\ (Suatu Kasus Di Desa Rejasari Kecamatan Langensari Kota Banjar) \\ TETI TRESNANINGSIH, DEDI HERDIANSAH S, TITO HARDIYANTO}

banyak yang menggunakan teknik jajar legowo 6:1, teknik jajar legowo 8:1, teknik jajar legowo 10:1, teknik jajar legowo 12:1 bahkan masih ada yang masih menggunakan sisitem tegel.

b. Penanaman bibit 1 sampai 3 per rumpun belum bisa dilaksanakan secara maksimal, karena masih ditemukannya serangan hama keong mas.

\section{Saran}

Berdasarkan kesimpulan, maka dapat diajukan saran sebagai berikut:

1) Penyuluhan tentang penerapan teknologi PTT baik komponen teknologi dasar maupun komponen teknologi pilihan perlu lebih diintensifkan agar seluruh anggota kelompok tani yang ada diwilayah Desa Rejasari Kecamatan Langensari Kota Banjar bisa menerapkan teknologi PTT sesuai anjuran, sehingga yang diharapkan dalam tujuan dari program PTT bisa tercapai yaitu meningkatkan produktivitas dan pendapatan petani padi sawah serta melestarikan lingkungan produksi melalui pengelolaan lahan, air, tanaman, OPT dan iklim secara terpadu.

2) Program pemerintah dalam kegiatan demplot padi sawah perlu lebih ditinggkatkan agar petani bisa melihat contoh dari kegiatan demplot tersebut terutama dalam penerapan sistem tanam jajar legowo 2: 1.

3) Harus lebih diintensifkan pemberantasan hama keong agar cara tanam dengan penanaman 1 sampai 3 bibit per rumpun dapat dilaksanakan secara optimal.

\section{DAFTAR PUSTAKA}

Arikunto. 2002. Prosedur Penelitian. Rineka Cipta (Jakarta, 2002)

Balai Penyuluhan Pertanian Kecamatan Langensari. 2014. Data Produksi Padi sawah Kecamatan Langensari Kota Banjar. Banjar.

Badan Pusat Statistik Republik Indonesia, 2011). Data Produksi Tanaman Pangan. Jakarta.

Balai Pengkajian Teknologi Pertanian Jawa Barat. 2011. Petunjuk Teknis Pengelolaan Tanaman Terpadu (PTT) Padi Sawah. Bandung
Daniel, Moehar. 2002. Metode Penelitian Sosial Ekonomi. PT. Bumi Aksara. Jakarta.

Dinas Pertanian dan Ketahanan Pangan Kota Banjar. 2014. Laporan Tahunan Bidang Tanaman Pangan dan Hortikultura Tahun 2014. Banjar.

Dinas Pertanian Tanaman Pangan Provinsi Jawa Barat. 2013. Upaya Peningkatan Produksi Tanaman Pangan di Jawa Barat. Bandung.

Kementerian Pertanian republik Indonesia. 2013. Pedoman Teknis Sekolah Lapang Pengelolaan Tanaman Terpadu (SL-PTT) Padi dan Jagung. Jakart

Slamet, M. 2003. Membentuk Pola Perilaku Manusia Pembangunan. Cetakan Pertama. IPB press. Bandung

Soekanto. 2000. Sosiologi Suatu Pengantar. Bina Cipta. Bandung. 
Jurnal IImiah Mahasiswa AGROINFO GALUH

Volume 2 Nomor 2, Januari 2016

Halaman | 144 